\title{
Elemental concentrations in deposited dust on leaves along an urbanization gradient ${ }^{\text {th }}$
}

\author{
Edina Simon ${ }^{\mathrm{a}, *}$, Edina Baranyai ${ }^{\mathrm{b}, \mathrm{c}}$, Mihály Braun ${ }^{\mathrm{d}}$, Csaba Cserháti ${ }^{\mathrm{e}}$, István Fábián ${ }^{\mathrm{b}}$, Béla Tóthmérész ${ }^{\mathrm{f}}$ \\ a Department of Ecology, University of Debrecen, H-4010 Debrecen, P.O. Box 71, Hungary \\ ${ }^{\mathrm{b}}$ Department of Inorganic and Analytical Chemistry, University of Debrecen, H-4010 Debrecen, P.O. Box 21, Hungary \\ c Agilent Atomic Spectroscopy Partner Laboratory, University of Debrecen, Egyetem tér 1, H-4032 Debrecen, Hungary \\ d Institute of Nuclear Research of the Hungarian Academy of Sciences, Herteleni Laboratory of Environmental Studies, 4026 Debrecen, Bem tér 18/C, Hungary \\ e Department of Solid State Physics, University of Debrecen, H-4010 Debrecen, P.O. Box 2, Hungary \\ ${ }^{\mathrm{f}}$ HAS-UD Biodiversity and Ecosystem Services Research Group, H-4010 Debrecen, P.O. Box 71, Hungary
}

\section{H I G H L I G H T S}

- Dust is used as indicators of the accumulation of inorganic pollutants.

- Scanning EM was used to explore the morphological structure of leaves.

- Amount of dust deposited of leaves correlated with trichomes' density.

- A. negundo, C. occidentalis and $Q$. robur are suitable to indicate air contaminants.

- A. negundo and $C$. occidentalis are suitable to decrease the amount of dust in air.

\section{A R T I C L E I N F O}

\section{Article history:}

Received 13 March 2014

Received in revised form 29 April 2014

Accepted 7 May 2014

Available online $\mathrm{xxxx}$

Editor: P. Kassomenos

\section{Keywords:}

Urbanization

Stomata density

Stomata size

Heavy metals

Trichomes

\begin{abstract}
A B S T R A C T
Environmental health is an essential component of the quality of life in modern societies. Monitoring of environmental quality and the assessment of environmental risks are often species based on the elemental concentration of deposited dust. Our result suggested that stomata size and distribution were the most important factors influencing the accumulation of air contaminants in leaves. We found that the leaves' surfaces of Acer negundo and Celtis occidentalis were covered by a large number of trichomes, and these species have proven to be suitable biomonitors for atmospheric pollution difficult; these can be overcome using bioindicator species. Leaves of Padus serotina, Acer campestre, A. negundo, Quercus robur and C. occidentalis were used to assess the amount of deposited dust and the concentration of contaminants in deposited dust in and around the city of Debrecen, Hungary. Samples were collected from an urban, suburban and rural area along an urbanization gradient. The concentrations of $\mathrm{Ba}, \mathrm{Cu}, \mathrm{Fe}, \mathrm{Mn}, \mathrm{Ni}, \mathrm{Pb}, \mathrm{S}, \mathrm{Sr}$ and $\mathrm{Zn}$ were determined in deposited dust using ICP-OES. Scanning electron microscopy (SEM) was used to explore the morphological structure and dust absorbing capacity of leaves. We found significant differences in dust deposition among species, and dust deposition correlated with trichomes' density. Principal component analysis (PCA) also showed a total separation of tree.
\end{abstract}

(C) 2014 Published by Elsevier B.V.

\section{Introduction}

The urban environment is a dominant habitat for humans (DuzgorenAydin et al., 2006). The rapid urbanization has resulted in the emission of several pollutants in the urban environment (Ahmed and Ishiga, 2006). Pollutants may enter to the urban environment from the atmosphere as gases, particles or aerosols, or by evaporation of liquids, from water by

\footnotetext{
is Stomata size and distribution are important factors influencing the accumulation of air contaminants in leaves.

* Corresponding author. Tel.: + 3652512 900; fax: + 3652431148

E-mail address: edina.simon@gmail.com (E. Simon).
}

coevaporation of dissolved solvents and erosion of soil by wind (Ordónez et al., 2003). Many studies have focused on the elemental concentration of heavy metals and other contaminants (Al-Khashman, 2004; Apeagyei et al., 2011). Urbanization results in the deposition of pollutants and other toxic substances causing the degradation of environmental conditions (Duzgoren-Aydin et al., 2006).

Leaves are sensitive and highly exposed to air pollution (Prusty et al., 2005). Thus, in many studies tree leaves were used as indicators to assess the quality of air in urban environments (Aksoy et al., 2000; Al-Khlaifat and Al-Khashman, 2007; Olowoyo et al., 2010). Leaves can trap various airborne particles such as trace elements, pollens, spores and salts. Thus, they are good accumulators of atmospheric 
contaminants (Lohr and Pearson-Mims, 1996). The capacity of leaves as dust trap depends on such factors as surface geometry, phyllotaxy, epidermal and cuticular features, leaf pubescence, and height and canopy of trees (Singh et al., 2005). Leaves collect dust on their leaf surface and trichomes (Lohr and Pearson-Mims, 1996). They could absorb gaseous pollutants via their stomata which interact between plants and their environment (Morani et al., 2011; Kardel et al., 2010); in this aspect leaves are active air contaminant collectors. On the other hand, leaves collect and deposit dust via their trichomes; thus they are also passive dust traps (Schulze and Hall, 1982; Pallardy, 2008).

In air pollution studies the leaf surface with trichomes, the size of stomata and stomatal density are the most important factors (Abbruzzese et al., 2009). Brighigna et al. (2002) studied peculiar peltate trichomes in Tillandsia species. These trichomes are qualified to catch aerosols and these increase the plain-tair interferences. Their studies also demonstrated that leaves by their trichomes are suitable for air pollution monitoring (Brighigna et al., 2002). Dust trap and air contaminant accumulation capability are highly dependent on the morphological and anatomical parameters of leaves. This aspect is demonstrated in an earlier study with the biomonitoring of epiphyte species of the genus Tillandsia (Brighigna et al., 2002). Therefore, the purpose of this study was to analyze the amount of dust and the elemental concentration of air contaminants in the deposited dust (Ba, Cu, Fe, Mn, Ni, $\mathrm{Pb}, \mathrm{S}, \mathrm{Sr}$ and $\mathrm{Zn}$ ) along an urbanization gradient. By scanning electron microscopy (SEM) analysis we explored the interaction between morphological and anatomical parameters as well as the dust trapping and air contaminant accumulation capability of leaves. Our hypothesis was that the species best catch dust on its leaves and they could be useful biomonitors of atmospheric particulate matter.

\section{Material and methods}

\subsection{Sampling sites and species}

Sampling areas were in and around the city of Debrecen (Hungary). Debrecen is at a height of $120 \mathrm{~m}$ above the sea level on a nearly flat terrain of the Great Hungarian Plain (Kircsi and Szegedi, 2003). Mixed meteorological effects are typical in Debrecen because the city is located near to the border of different climatic zones. The prevailing wind direction is northwestern in Debrecen which could bring aerosol in the form of interregional transport (Dobos et al., 2009).

Along an urbanization gradient three sampling areas were chosen representing a decreasing level of urbanization (urban, suburban and rural). The urban sampling area $\left(48^{\circ} 33^{\prime} \mathrm{N} 21^{\circ} 37^{\prime} \mathrm{E}\right)$ was located in a forested park of the city with heavy traffic around. The suburban area $\left(47^{\circ} 33^{\prime} \mathrm{N} 21^{\circ} 36^{\prime} \mathrm{E}\right)$ was in a forested suburban area with lower traffic and other anthropogenic activities. The rural area $\left(47^{\circ} 35^{\prime} \mathrm{N} 21^{\circ} 36^{\prime} \mathrm{E}\right)$ was in a protected forest (Nagyerdő Forest Reserve Area) where the traffic and visitor pressure were low which resulted in a more natural and undisturbed character of this area. Formerly, all sampling areas were covered by oak forest (Convollario-Quercetum roburis) (Török and Tóthmérész, 2004).

Within each sampling area four sites were selected, and 3 tree individuals were chosen randomly in each site. Ten leaves were collected from each tree individual from $1.5 \mathrm{~m}$ high during August 2010. In each site there were two pooled samples which contained 30 leaves each, collected from 3 tree individuals; i.e. 10 leave samples were collected from one tree individual. Thus, altogether we collected $2 * 30=60$ leaves from each sampling site. Leaves of Padus serotina, Acer campestre, Acer negundo, Quercus robur and Celtis occidentalis were collected. Samples were collected in plastic bags and they were stored at $+4{ }^{\circ} \mathrm{C}$ in the dark for analysis.

\subsection{Sample preparation}

We used a flat bed scanner to determine the surface area of leaves. The deposited dust was washed down from leaves by deionized water. The leaves were put into a $500 \mathrm{~mL}$ plastic box and $250 \mathrm{~mL}$ of deionized water was added, then samples were shaken for $10 \mathrm{~min}$. The dust containing suspension was filtered through a $150 \mu \mathrm{m}$ sieve. The leaves were washed with $50 \mathrm{~mL}$ deionized water again, then filtered and added to the samples. This $300 \mathrm{~mL}$ of dust containing suspension was transferred into a microwave oven, where its volume was reduced to 20-30 mL. After the suspension was transferred into $50 \mathrm{~mL}$ glass beakers, the rest of the water was evaporated at $105^{\circ} \mathrm{C}$. The beakers were reweighted to determine the dry weight of deposited dust. Samples were prepared for analysis in the same vessels. They were digested using $5 \mathrm{~mL}$ of $65 \%(\mathrm{~m} / \mathrm{m})$ nitric acid and $2 \mathrm{~mL}$ of $30 \%(\mathrm{~m} / \mathrm{m})$ hydrogen-peroxide at $80{ }^{\circ} \mathrm{C}$ for $4 \mathrm{~h}$. Digested samples were diluted to $10 \mathrm{~mL}$ using $1 \%(\mathrm{~m} / \mathrm{m})$ nitric acid and then the samples were diluted to $25 \mathrm{~mL}$ with deionized water (Simon et al., 2011). During digestion 10 blanks were used.

\subsection{Determination of $\mathrm{Ba}, \mathrm{Cu}, \mathrm{Fe}, \mathrm{Mn}, \mathrm{Ni}, \mathrm{Pb}, \mathrm{S}, \mathrm{Sr}$ and $\mathrm{Zn}$ in deposited dust}

Inductively coupled plasma-optical emission spectrometry (ICPOES) with IRIS Intrepid II XSP instrument was used during the elemental analysis. We used a six-point calibration procedure with multi-element calibration solution (Merk ICP multi-element standard solution IV).

\subsection{Scanning electron microscopy}

Scanning electron microscopy (SEM) was used to investigate the surface of leaves as well as the size and density of the stomata of the species. Sections $\left(5 \times 7 \mathrm{~mm}^{2}\right)$ were cut from leaves, and dehydrated in ethanol solutions of $30 \%, 50 \%, 70 \%, 90 \%$ and $100 \%$ for 10 min each. The sections were gold coated using an SEM coating unit PS3 evaporator. The samples were examined with an S-4300 CFE Hitachi SEM at $5.0 \mathrm{kV}$ accelerating voltage.

\subsection{Statistical analysis}

Calculations were performed using the SPSS/PC + and Canoco for Windows 4.5 statistical software packages. The normal distribution was tested with a Shapiro-Wilk test. The homogeneity of variances was tested with Levene's test. Principal Component Analysis (PCA) was used to display the effect of tree species and urbanization on the elemental concentration of foliage dust. The amount of dust on the surface of leaves, stomata size of leaves and the elemental concentration of foliage dust of the studied areas were compared by a two-way ANOVA where one factor was the studied sites and the other factor was the tree species. As post hoc test LSD Multiple Comparison test was used to explore the significant differences.

\section{Results}

\subsection{Amount of deposited dust on leaves}

The effect of urbanization and tree species on the amount of deposited dust on the leaves was analyzed by a two way ANOVA. The tree species had a significant effect on the amount of dust $\left(F_{14,45}=64.661\right.$, $p<0.001)$. The degree of urbanization had no significant effect on the amount of deposited dust $\left(\mathrm{F}_{14,45}=4.591, p=0.068\right)$ while the interaction of the urbanization and species was significant $\left(F_{14,45}=3.786, p<0.01\right)$. The amount of deposited dust was the highest in all areas for the $A$. negundo and $C$. occidentalis. The amount of deposited dust was the lowest in all areas for P. serotina, A. campestre and $Q$. robur. There was no significant difference in the amount of deposited dust on the surface of $A$. negundo and C. occidentalis ( $p>0.05$ ). There was no significant difference in the amount of deposited dust among $P$. serotina, $A$. campestre, and $Q$. robur in the rural and suburban areas $(p>0.05)$. In the urban area a significant difference was found in the amount of deposited dust between these species $(p<0.05)$. We 
found no significant differences along the urbanization gradient (rural, suburban and urban areas) by LSD test (Fig. 1).

\subsection{The concentration of air contaminants in deposited dust on leaves}

PCA showed a total separation of tree species based on the concentration of air contaminants in the deposited foliage dust (Fig. 2). The first component (PC1) contributed to $80.2 \%$ of the total variance, while the second one (PC2) contributed $7.7 \%$ of the total variance. There were two groups of elements separated along the first axis (PC1). The first group of elements included the following elements: $\mathrm{Sr}, \mathrm{Ba}, \mathrm{Cu}, \mathrm{Ni}$, $\mathrm{Pb}$ and $\mathrm{Zn}$. The second group was comprised by the following elements: $\mathrm{S}, \mathrm{Mn}$ and Fe. Species and species-urbanization interaction affected significantly the concentration of $\mathrm{Ba}, \mathrm{Cu}, \mathrm{Ni}, \mathrm{Pb}$ and $\mathrm{Sr}$ in the deposited dust $(p<0.05)$. The Fe and Mn concentrations changed significantly by species, urbanization and species-urbanization interaction $(p<0.05)$ (see Supplementary Data 1 ). The species and urbanization influenced significantly the concentration of $S(p<0.01)$. There was a significant difference in the $\mathrm{Zn}$ concentration $(p<0.001)$ between the species (see Supplementary Data 1 ). In the case of $P$. serotina a significantly higher $\mathrm{Cu}$ and Fe concentration was found in the deposited dust in the urban area than in the suburban and rural areas. The $\mathrm{Pb}$ concentration was not different between the urban and rural areas; there was a significant difference only in the case of the suburban area (Table 1). In the rural area a significantly lower $\mathrm{S}$ concentration was found than in the suburban and urban areas. In the case of deposited dust of A. campestre the Mn and Ni concentrations was significantly higher in the suburban area than in the urban and rural areas. There was no significant difference in $\mathrm{Ni}$ concentration between the suburban and

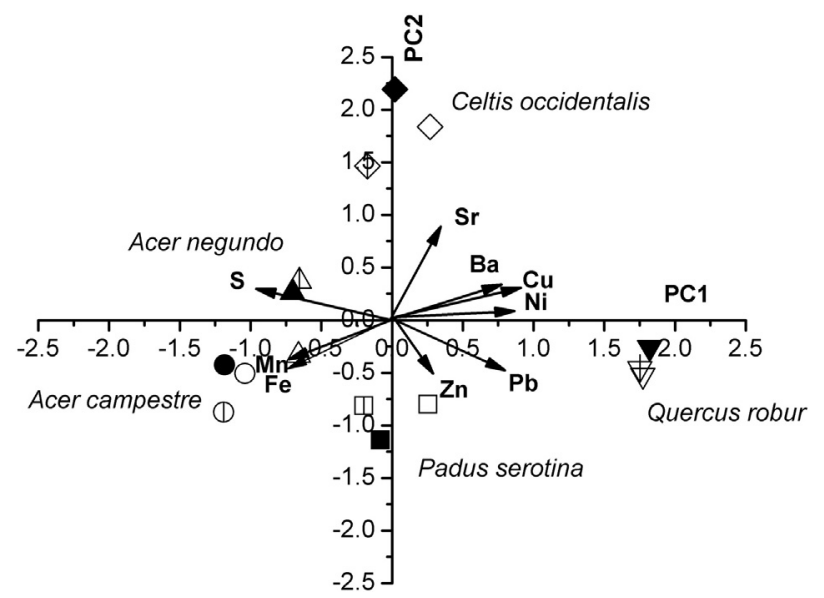

Fig. 2. Principal component biplot of element concentrations of deposited dust of species and study areas. Notations: Padus serotina: $\square$ - rural area, $\square-$ suburban area, $\square$ - urban area; Acer campestre: $\bigcirc$ - rural area, $(1$ - suburban area, - - urban area; Quercus robur: $\Delta$ - rural area, $₫$ - suburban area, $\boldsymbol{\Delta}$ - urban area; Acer negundo: $\nabla-$ rural area, $\nabla$ - suburban area, $\nabla$ - urban area; and Celtis occidentalis: $\diamond$ - rural area, 0 - suburban area, $\bullet$ urban area.

rural areas $(p>0.05)$. In the suburban area the Mn concentration was also the highest in the deposited dust of $Q$. robur but there were no differences between the suburban and rural areas. In the deposited dust of A. negundo the $\mathrm{Ba}$ and $\mathrm{Sr}$ concentrations were the highest in the urban area (Table 1). The Mn and Ni concentrations were the highest in the rural area in the deposited dust of $C$. occidentalis.
A
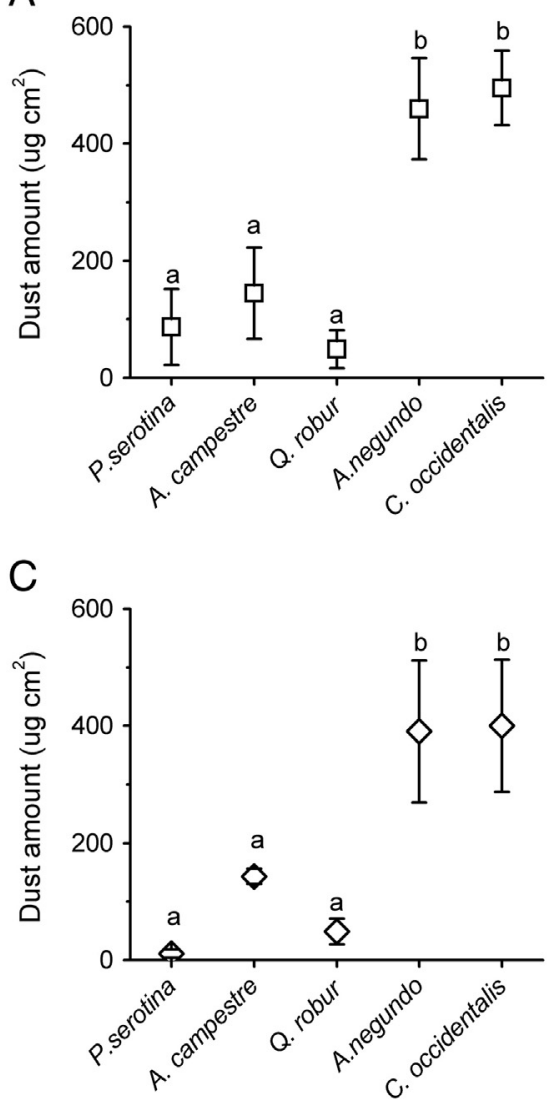

$\mathrm{B}$

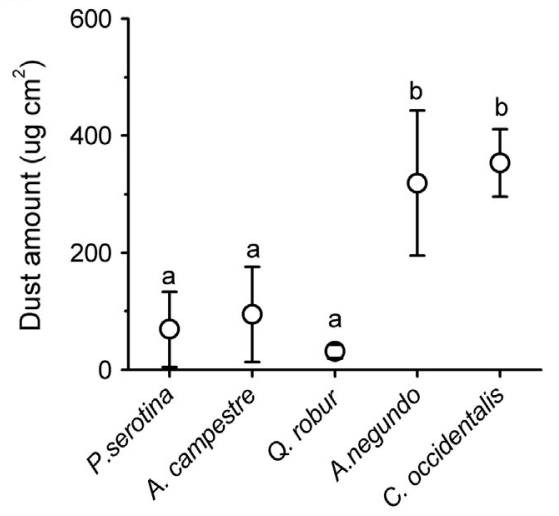

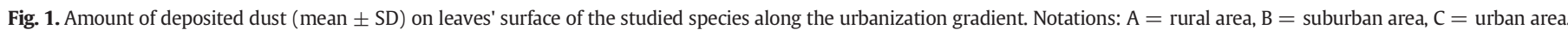
Different letters indicate significant differences $(p<0.05)$. 
Table 1

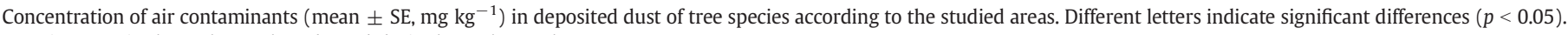
Notations: "a" is always lower than "b" and "b" is always lower than "c".

\begin{tabular}{|c|c|c|c|c|c|c|c|c|c|c|}
\hline & & & & & & ontaminan & & & & \\
\hline Species & Area & $\mathrm{Ba}$ & $\mathrm{Cu}$ & $\mathrm{Fe}$ & Mn & $\mathrm{Ni}$ & $\mathrm{Pb}$ & S & $\mathrm{Sr}$ & $\mathrm{Zn}$ \\
\hline \multirow{3}{*}{ 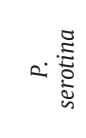 } & Rural & $38 \pm 9$ & $17 \pm 3^{a}$ & $388 \pm 145^{\mathrm{a}}$ & $609 \pm 277$ & $25 \pm 5$ & $17 \pm 8^{\mathrm{a}}$ & $1223 \pm 255^{\mathrm{a}}$ & $43 \pm 6$ & $91 \pm 12$ \\
\hline & Suburban & $41 \pm 12$ & $22 \pm 6^{\mathrm{a}}$ & $339 \pm 97^{\mathrm{a}}$ & $1100 \pm 166$ & $22 \pm 6$ & $6 \pm 2^{\mathrm{ab}}$ & $2188 \pm 689^{b}$ & $37 \pm 9$ & $112 \pm 42$ \\
\hline & Urban & $96 \pm 25$ & $70 \pm 23^{b}$ & $2009 \pm 718^{b}$ & $828 \pm 275$ & $120 \pm 94$ & $43 \pm 16^{b}$ & $6400 \pm 2138^{b}$ & $145 \pm 84$ & $385 \pm 138$ \\
\hline \multirow{3}{*}{ 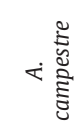 } & Rural & $15 \pm 3$ & $7 \pm 1$ & $286 \pm 36$ & $718 \pm 111^{a}$ & $3 \pm 1^{\mathrm{a}}$ & $3 \pm 1$ & $5699 \pm 1647$ & $28 \pm 3$ & $54 \pm 4$ \\
\hline & Suburban & $35 \pm 8$ & $15 \pm 3$ & $492 \pm 114$ & $2470 \pm 496^{c}$ & $7 \pm 2^{\mathrm{b}}$ & $11 \pm 4$ & $12079 \pm 1770$ & $29 \pm 2$ & $119 \pm 29$ \\
\hline & Urban & $16 \pm 2$ & $7 \pm 1$ & $289 \pm 32$ & $224 \pm 20^{b}$ & $1 \pm 1^{\mathrm{b}}$ & $5 \pm 1$ & $10012 \pm 3278$ & $23 \pm 7$ & $79 \pm 10$ \\
\hline \multirow{3}{*}{ 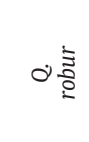 } & Rural & $65 \pm 16$ & $27 \pm 6$ & $2439 \pm 856$ & $1274 \pm 396^{\mathrm{b}}$ & $37 \pm 20$ & $27 \pm 6$ & $3060 \pm 880$ & $57 \pm 18$ & $159 \pm 24$ \\
\hline & Suburban & $42 \pm 14$ & $31 \pm 7$ & $915 \pm 128$ & $1686 \pm 155^{\mathrm{b}}$ & $19 \pm 2$ & $14 \pm 6$ & $4298 \pm 1112$ & $22 \pm 7$ & $138 \pm 38$ \\
\hline & Urban & $44 \pm 13$ & $30 \pm 7$ & $1472 \pm 184$ & $348 \pm 90^{\mathrm{a}}$ & $13 \pm 1$ & $26 \pm 5$ & $3632 \pm 737$ & $18 \pm 8$ & $137 \pm 41$ \\
\hline \multirow{3}{*}{ 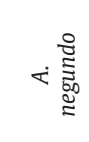 } & Rural & $8 \pm 2^{a}$ & $7 \pm 3$ & $123 \pm 15$ & $219 \pm 15$ & $2 \pm 1$ & $2 \pm 1$ & $2081 \pm 402$ & $16 \pm 4^{\mathrm{a}}$ & $30 \pm 4$ \\
\hline & Suburban & $24 \pm 6^{\mathrm{a}}$ & $10 \pm 2$ & $243 \pm 77$ & $248 \pm 44$ & $3 \pm 1$ & $3 \pm 1$ & $3582 \pm 1038$ & $45 \pm 8^{\mathrm{b}}$ & $42 \pm 10$ \\
\hline & Urban & $33 \pm 11^{\mathrm{b}}$ & $7 \pm 1$ & $225 \pm 40$ & $656 \pm 268$ & $1 \pm 1$ & $1 \pm 1$ & $1574 \pm 119$ & $60 \pm 12^{b}$ & $35 \pm 8$ \\
\hline \multirow{3}{*}{ 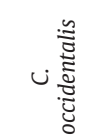 } & Rural & $20 \pm 2$ & $13 \pm 3$ & $42 \pm 20$ & $165 \pm 54^{\mathrm{b}}$ & $14 \pm 4^{\mathrm{b}}$ & $1 \pm 1$ & $1564 \pm 442$ & $70 \pm 9$ & $27 \pm 7$ \\
\hline & Suburban & $17 \pm 6$ & $18 \pm 4$ & $95 \pm 14$ & $71 \pm 16^{\mathrm{ab}}$ & $4 \pm 1^{\mathrm{a}}$ & $1 \pm 1$ & $2311 \pm 279$ & $59 \pm 14$ & $38 \pm 5$ \\
\hline & Urban & $23 \pm 3$ & $16 \pm 4$ & $92 \pm 23$ & $46 \pm 15^{\mathrm{a}}$ & $4 \pm 1^{\mathrm{a}}$ & $1 \pm 1$ & $1985 \pm 271$ & $138 \pm 24$ & $30 \pm 3$ \\
\hline
\end{tabular}

\subsection{Structure of leaves' surface, stomata density and stomata size}

Scanning electron microscopy (SEM) images showed that there were no trichomes in the epidermis of $P$. serotina and $Q$. robur (Fig. 3A and $C$ ). Occasionally, there were trichomes in the epidermis of A. campestre and A. negundo. The occasional occurrences of trichomes facilitate the adsorption of dust particles (see Fig. 3B and D). In the case of C. occidentalis a large number of trichomes were found in the epidermis. Moreover, the sizes of trichomes were extremely diverse (Fig. 3E).

The highest stomata density was found in A. negundo (757 \pm 26 stomata $\mathrm{mm}^{-2}, \mathrm{~N}=3$ ) (Fig. 4D). Lower stomata density was found on the leaves of $A$. campestre ( $568 \pm 47$ stomata $\mathrm{mm}^{-2}, \mathrm{~N}=3$ ) (Fig. 4B), and C. occidentalis ( $511 \pm 12$ stomata $\mathrm{mm}^{-2}, \mathrm{~N}=3$ ) (Fig. 4E) than on the leaves of $A$. negundo. The lowest stomata density was found on the leaves of $Q$. robur ( $338 \pm 65$ stomata $\mathrm{mm}^{-2}, \mathrm{~N}=3$ ) (Fig. 4C). The lowest stomata density occurred on the leaves of P. serotina ( $237 \pm 33$ stomata $\mathrm{mm}^{-2}, \mathrm{~N}=3$ ) (Fig. 4A).

Significant differences were found among the stomata size $\left(\mathrm{F}_{4,234}=\right.$ $111.155, p<0.001)$. The highest stomata size was found on leaves of Q. robur $(22.6 \pm 0.4 \mu \mathrm{m})$. On the leaves of $P$. serotina significantly smaller stomata $(19.9 \pm 0.5 \mu \mathrm{m})$ occurred than on the leaves of $Q$. robur, but higher than on the leaves of other species $(p<0.001)$. There was no significant difference among the stomata size of $C$. occidentalis (13.3 \pm $0.2 \mu \mathrm{m})$ and the other species. There were significant differences in the stomata size between $A$. campestre $(14.5 \pm 0.4 \mu \mathrm{m})$ and A. negundo $(16.5 \pm 0.6 \mu \mathrm{m})(p<0.05)$.

\section{Discussion}

The amount of deposited dust is widely used in environmental pollution studies (Prusty et al., 2005; Freer-Smith et al., 2005). Prusty et al. (2005) observed an increased amount of deposited dust around sites with elevated traffic flow. A significant difference was found in the overall loaded amount of deposited dust on leaves between an urban park and a pasture land in London, where the particle uptake was higher at the urban site than at the rural area (Freer-Smith et al., 2005). They reported a significant effect of species and sites on the amount of deposited dust (Freer-Smith et al., 2005). Contrasted with their findings in our study no significant difference occurred in the amount of deposited dust along the urbanization gradient. This is caused by the meteorological and landscape characteristics of Debrecen city. The city is in the bottom of a basin, so the dust and air contaminants can accumulate in this city in high ratio. In the past 20 years the increasing traffic and industrial activities present higher air pollution (Kertész et al., 2008). Singh and Jothi (1999) and Garg et al. (2000) have also reported that the amount of deposited dust is highly dependent on the characteristic features of leaf surfaces. Similarly to our study Wang et al. (2006) investigated the correlation between the morphology and anatomy of leaf surface of plant species and the density of settling particles. They found that larger micro-roughness of a leaf surface captured higher amount of deposited dust. We found the highest amount of particles on the leaf surface of $C$. occidentalis and $A$. negundo in each investigated areas as well as these species showed the largest trichome density according to the SEM analysis. These two species contributed most effectively to the removal of urban deposited dust particles from the air. The lowest particle density occurred in the case of $P$. serotina and $Q$. robur that also showed a good correlation with the scanning electron-microscopic findings, since their surface was found to be the smoothest with the lack of trichomes. Tomašević and Aničić (2011) and Prusty et al. (2005) also explained the differences in the amount of deposited dust by the different epidermal characteristics and leaf structures.

In deposited dust samples among air contaminants the $\mathrm{Pb}$ concentration was lower in our study than in other findings (Al-Khlaifat and Al-Khashman, 2007; Apeagyei et al., 2011; Duong and Lee, 2011). There was high traffic in these areas. Lead is added to gasoline as organic tetraalkyl lead additives, so the main source of $\mathrm{Pb}$ is leaded gasoline 

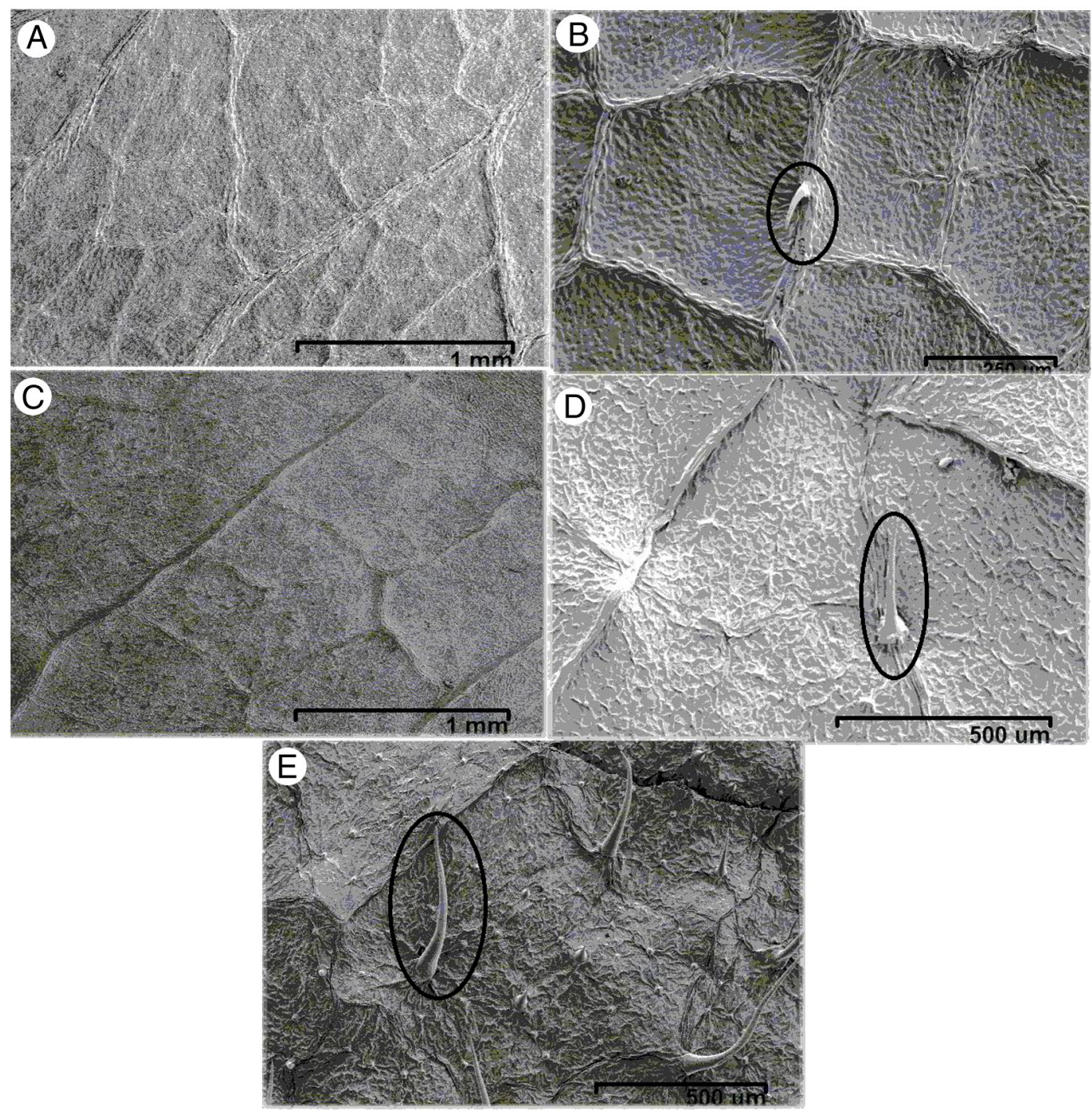

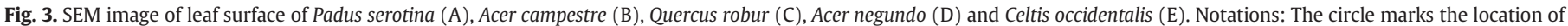
trichomes.

(Al-Khlaifat and Al-Khashman, 2007; Thomas, 1995). Before April 1999 cars had used leaded petrol in Hungary. The lead concentration may derive from leaded petrol in environment because of lead remains in the soil for centuries (Szegedi, 2007). In spite of the removal of leaded petrol diffuse emissions (wear and tear of brake pads of cars) may cause $\mathrm{Pb}, \mathrm{Cu}$ and Zn pollution (Al-Khlaifat and Al-Khashman, 2007).

Earlier reports also founded a higher $\mathrm{Cu}$ concentration in high traffic area than in our study (Apeagyei et al., 2011; Duong and Lee, 2011). We found a higher $\mathrm{Cu}$ concentration in the deposited dust of $P$. serotina and Q. robur in the urban area than results in an earlier study (Al-Khlaifat and Al-Khashman, 2007). The source of $\mathrm{Cu}$ was ascribed to corrosion of the metallic parts of cars as engineer wear, thrust bearing and brush wear (Meza-Figueroa et al., 2007). Similar to the $\mathrm{Cu}$ the $\mathrm{Zn}$ originated from car components such as tire abrasion, so tire treads and tire dust contain a large amount of Zn (Meza-Figueroa et al., 2007). In our study we found similar results of $\mathrm{Zn}$ concentration in deposited dust than in earlier studies (Apeagyei et al., 2011; Al-Khlaifat and Al-Khashman, 2007; Duong and Lee, 2011). The Ni concentration was higher in our study in deposited dust of $P$. serotina from urban area and in deposited dust of $Q$. robur than in earlier studies (Al-Khlaifat and Al-Khashman, 2007; Duong and Lee, 2011). Pacyna et al. (2007) reported that in the urban areas Ni mostly originated from the fossil fuel combustion stationary sources. The corrosion of cars and chrome plating of motor vehicle parts may also result in high concentration of $\mathrm{Ni}$ in dust in an urban environment (Christoforidis and Stamatis, 2009). Besides the $\mathrm{Cu}$, the brake housing dust and crushed brake pads contain a high concentration of Fe (Adachi and Tainoshob, 2004; Schauer et al., 2006). In our study the Fe concentration was higher in the deposited dust than in the study of Al-Khlaifat and Al-Khashman (2007) but lower than in an earlier study (Apeagyei et al., 2011).

Our study indicated that the morphology and anatomy of leaves were important when they were used as environmental-quality indicator. The surface of leaves, and the size and density of trichomes were important in the dust deposition. Our study demonstrated that on the leave's surface of $P$. serotina and $Q$. robur the trichome density was low, so the dust absorbing capability of these species was also low. We found the highest trichome density on $C$. occidentalis leaves, and this resulted in a high dust absorbing capability. We also demonstrated that stomata size and density also play an important role in the accumulation of air contaminants in leaves. Tomašević and Aničić (2011) observed that most of the fine particles were deposited near the stomata, around and over, by which the physiological characteristics of leaves can be affected. Similar to their results we also demonstrated that the high size of stomata and/or high density of stomata may result in a high concentration of air contaminants in contrast with the small stomata size. 


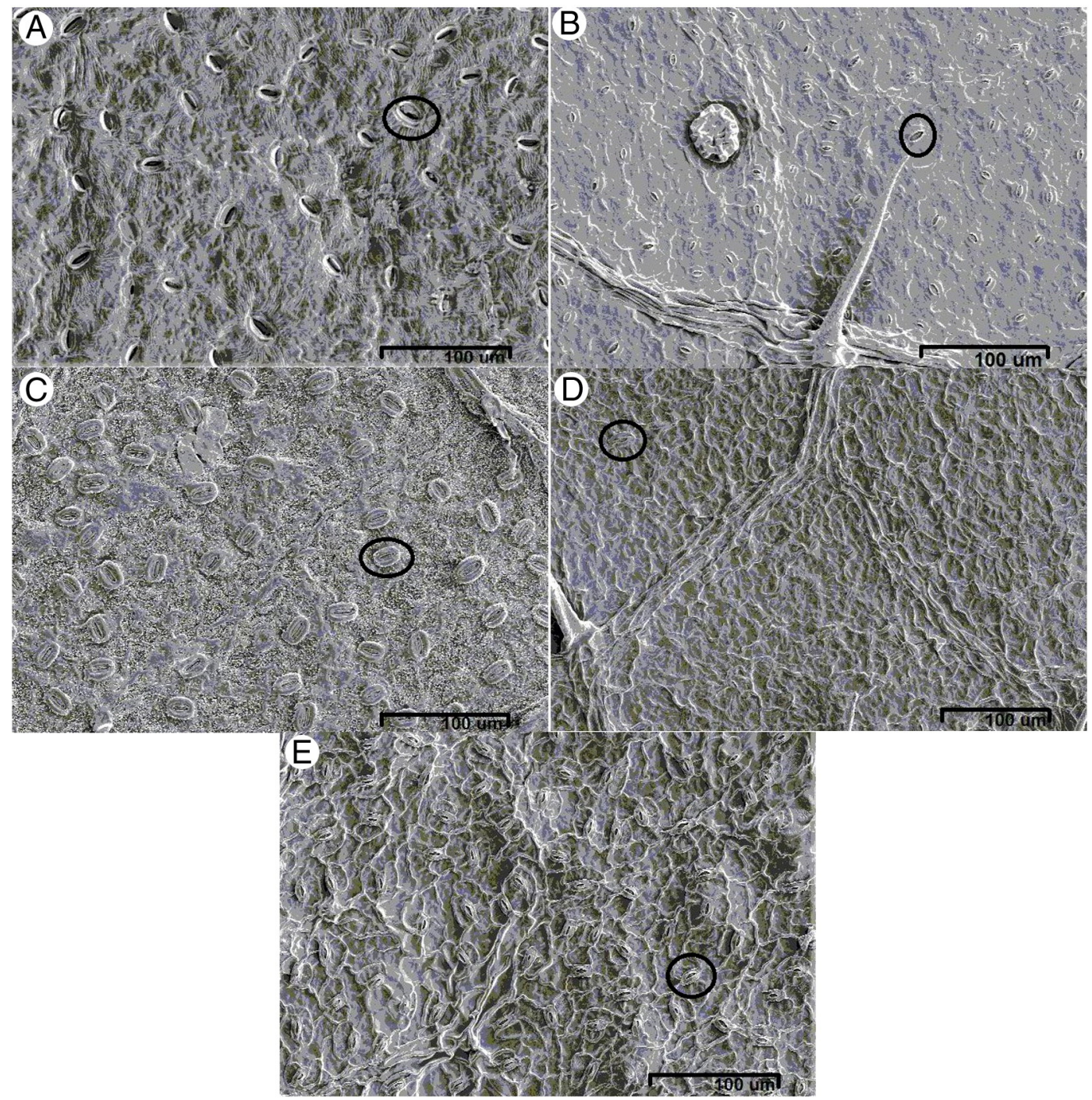

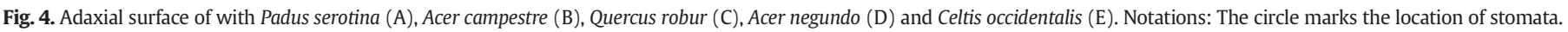

\section{Conclusions}

Our study demonstrated that A.negundo, C. occidentalis and Q. robur were useful biological indicators because of their large stomata size and high stomata density We found that the leaves' surface of A. negundo and C. occidentalis is covered by a large number of trichomes, which made them especially suitable to decrease the level of air pollution. Our results show that the density of trichome, stomata size and density were important in dust deposition. Leaves with a high trichome density can deposit a larger amount of dust, so these tree species may decrease the amount of dust from air in urban and contaminated areas.

Supplementary data to this article can be found online at http://dx. doi.org/10.1016/j.scitotenv.2014.05.028.

\section{Acknowledgment}

The work is supported by the TÁMOP 4.2.1/B-09/1/KONV-20100007 and TÁMOP 4.2.2/B-10/1-2010-0024 projects. The project is implemented through the New Hungary Development Plan, co-financed by the European Social Fund and the European Regional Development Fund. E. Simon was supported by the European Union and the State of Hungary, co-financed by the European Social Fund in the framework of TÁMOP 4.2.4.A/2-11-1-2012-0001 'National Excellence Program'.

\section{References}

Abbruzzese G, Beritognolo I, Muleo R, Piazzai M, Sabatti M, Mugnozza GS, et al. Leaf morphological plasticity and stomatal conductance in three Populus alba L. genotypes subjected to salt stress. Environ Exp Bot 2009;66:381-8.

Adachi K, Tainoshob Y. Characterization of heavy metal particles embedded in tire dust. Environ Int 2004;30:1009-17.

Ahmed F, Ishiga $\mathrm{H}$. Trace metal concentrations in street dusts of Dhaka city, Bangladesh. Atmos Environ 2006:40:3835-44.

Aksoy A, Sahin U, Duman F. Robinia pseudo-acacia L. as a possible biomonitor of heavy metal pollution in Kayseri. Turk J Bot 2000;24:279-84.

Al-Khashman OA. Heavy metal distribution in dust, street dust and soils from the work place in Karak Industrial Estate, Jordan. Atmos Environ 2004;38:6803-12.

Al-Khlaifat AL, Al-Khashman OA. Atmospheric heavy metal pollution in Aqaba city, Jordan, using Phoenix dactylifera L. leaves. Atmos Environ 2007:41:8891-7.

Apeagyei E, Bank MS, Spengler JD. Distribution of heavy metals in road dust along an urban-rural gradient in Massachusetts. Atmos Environ 2011;45:2310-23.

Brighigna L, Papini A, Mosti S, Cornia A, Bocchini P, Galletti G. The use of tropical bromeliads (Tillandsia spp.) for monitoring atmospheric pollution in the town of Florence, Italy. Rev Biol Trop 2002;50:577-84.

Christoforidis A, Stamatis N. Heavy metal contamination in street dust and roadside soil along the major national road in Kavala's region, Greece. Geoderma 2009;151: 257-63.

Dobos E, Borbély-Kiss I, Kertész Zs, Szabó Gy, Koltay E. Debrecen, Hungary on the finefraction aerosol map of Europe. J Radioanal Nucl Chem 2009;279:143-57.

Duong TTT, Lee BK. Determining contamination level of heavy metals in road dust from busy traffic areas with different characteristics. J Environ Manage 2011:92:554-62.

Duzgoren-Aydin NS, Wong CSC, Aydin A, Song Z, You M, Li XD. Heavy metal contamination and distribution in the urban environment of Guangzhou, SE China. Environ Geochem Health 2006;28:375-91. 
Freer-Smith PH, Beckett KP, Taylor G. Deposition velocities to Sorbus aria, Acer campestre, Populus deltoides trichocarpa 'Beaupre", Pinus nigra and Cupressocyparis leylandii for coarse, fine and ultra-fine particles in the urban environment. Environ Pollut 2005; 133:157-67.

Garg SS, Kumar N, Das G. Effects of the Bansal Ramraj mill dust on vegetation and health at Jaitwara, District Satna. Indian. J Environ Prot 2000;20:326-8.

Kardel F, Wuyts K, Babanezhad M, Vitharana UWA, Wuytack T, Potters G, et al. Assessing urban habitat quality based on specific leaf area and stomatal characteristics of Plantago lanceolata L. Environ Pollut 2010;158:788-94.

Kertész Zs, Szoboszlai Z, Dobos E, Borbély-Kiss I. Characterization of urban aerosol sources in Debrecen, Hungary. AGD Lands Environ 2008:1:57-67.

Kircsi A, Szegedi S. The development of the urban heat island studied on temperature profiles in Debrecen. Acta Clim Chorol 2003;36-37:63-9.

Lohr VI, Pearson-Mims CH. Particulate matter accumulation on horizontal surfaces in interiors: influence of foliage plants. Atmos Environ 1996;30:2565-8.

Meza-Figueroa D, De la O-Villanueva M, De la Parra LM. Heavy metals distribution in dust from elementary schools in Hermosillo, Sonora, Mexico. Atmos Environ 2007;41: 276-88.

Morani A, Nowak DJ, Hirabayashi S, Calfapietra C. How to select the best tree planting locations to enhance air pollution removal in the MillionTreesNYC initiative. Environ Pollut 2011;159:1040-7.

Olowoyo JO, van Heerden E, Fischer JL, Baker C. Trace metals in soil and leaves of Jacaranda mimosifolia in Tshwane area, South Africa. Atmos Environ 2010;14:1826-30.

Ordónez A, Loredo J, De Miguel E, Charlesworth S. Distribution of heavy metals in the street dusts and soils of an industrial city in northern Spain. Arch Environ Contam Toxicol 2003;44:160-70.

Pacyna EG, Pacyna JM, Fudala J, Strzelecka-Jastrzab E, Hlawiczka S, Panasiuk D. Current and future emissions of selected heavy metals to the atmosphere from anthropogenic sources in Europe. Atmos Environ 2007;41:8557-66.
Pallardy SG. Physiology of woody plants. 3rd ed. Elsevier Inc.; 2008

Prusty BAK, Mishra PC, Azeezb PA. Dust accumulation and leaf pigment content in vegetation near the national highway at Sambalpur, Orissa, India. Ecotoxicol Environ Saf 2005;60:228-35.

Schauer JJ, Lough GC, Shafer MM, Christensen WF, Arndt MF, DeMinter JT, et al. Characterization of metals emitted from motor vehicles. Health Eff Inst 2006;133:1-88.

Schulze ED, Hall AE. Stomatal responses, water loss and $\mathrm{CO}_{2}$ assimilation rates of plants in contrasting environments. In: Lange OL, et al, editors. Physiological plant ecology II, Encyclopedia of plant physiology 12/B. Springer; 1982.

Simon E, Braun M, Vidic A, Bogyó D, Fábián I, Tóthmérész B. Air pollution assessment based on elemental concentration of leaves tissue and foliage dust along an urbanization gradient in Vienna. Environ Pollut 2011;159:1229-33.

Singh P, Jothi S. Reduction in protein contents in a few plants as indicator of air pollution. Pollut Res 1999;18:281-3.

Singh A, Agrawal SB, Rathore D. Amelioration of Indian urban air pollution phytotoxicity in Beta vulgaris L. by modifying NPK nutrients. Environ Pollut 2005;134:385-95.

Szegedi S. Heavy metal loads in the soil of Debrecen. Acta Geogr Debrecina Lands Environ 2007;1:57-67.

Thomas VM. The elimination of lead in gasoline. Annu Rev Energy Environ 1995;20: 301-24.

Tomašević M, Aničić M. Trace element content in urban tree leaves and SEM-EDAX characterisation of deposited particles. FACTA UNIVERSITATIS Series. Phys Chem Techno 2011;8:1-13.

Török P, Tóthmérész B. A debreceni Nagyerdő növényzeti arculatának vizsgálata (In Hungarian). Botanical survey of the Nagyerdő Forest Reserve Area. Természetvédelmi Közlöny 2004;11:107-16

Wang L, Liu LY, Gao SY, Has E, Wang Z. Physicochemical characteristics of ambient particles settling upon leafsurfaces of urban plants in Beijing. J Environ Sci 2006;5 92l-926l. 